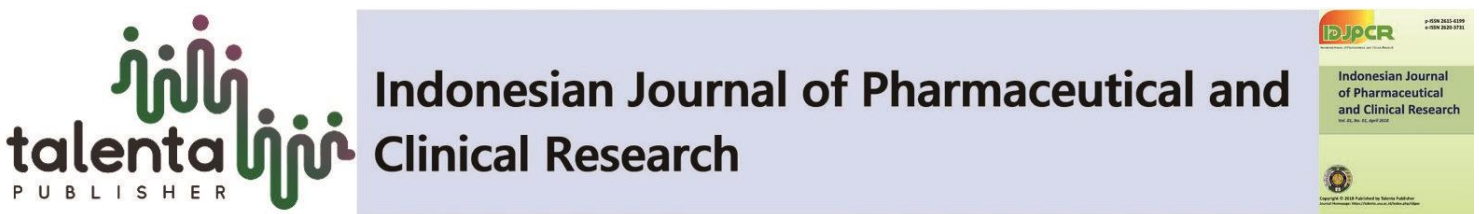

\section{Determination of Lead and Cadmium Added in Selected Lipstick Products Sold in Padang City Using Atomic Absorption Spectrophotometry}

\author{
Ridho Asra ${ }^{1}$, Rusdi ${ }^{1}$, Robi Budi Yandra ${ }^{1}$, and Nessa ${ }^{2}$ \\ ${ }^{1}$ School of Pharmaceutical Science (STIFARM) Padang, Indonesia \\ ${ }^{4}$ Indonesian Pharmaceutical College Perintis (STIFI) Padang, Indonesia
}

\begin{abstract}
The study was aimed to calculate the levels of toxic metals of lead and cadmium in selected lipstick products sold in Padang city. Four brands of lipsticks were taken which were BL, NK, PS and WD. The lipsticks were grinded and analyzed for heavy metals (lead and cadmium) using atomic absorption spectrophotometry. Each sample was destructed by nitric acid and perchloric acid (3:1). Destructed samples were added with sodium hydroxide to liberate ammonia and filtered into a $25 \mathrm{~mL}$ volumetric flask. The concentrations of heavy metal were measured by using atomic absorption spectrophotometry. The results showed that lead contamination was not detected. Whereas, the contamination of cadmium in lipstick brands BL, NK, PS and WD were $0.2287,0.2000,0.1796$ and $0.1220 \mathrm{mg} / \mathrm{kg}$, respectively. The study results showed that all metal contaminations of lead and cadmium were below maximum limit which were regulated by National Agency of Drug and Food Control of the Republic of Indonesia.
\end{abstract}

Keyword: Atomic Absorption Spectrophotometry, Cadmium, Lipstick, Lead.

Abstrak. Penelitian ini bertujuan untuk menentukan kadar beberapa logam beracun seperti timbal dan kadmium dalam produk lipstik tertentu yang dijual di kota Padang. Empat merek lipstick yang diambil yaitu BL, NK, PS dan WD. Lipstik digerus dan dianalisis kandungan logam berat (timbal dan kadmium) menggunakan spektrofotometri serapan atom. Setiap sampel didestruksi menggunakan asam nitrat dan asam perklorat (3: 1). Sampel hasil destruksi ditambahkan dengan natrium hidroksida untuk membebaskan amonia dan disaring ke dalam labu ukur $25 \mathrm{~mL}$. Konsentrasi logam berat diukur dengan menggunakan spektrofotometri serapan atom. Hasil penelitian menunjukkan bahwa kontaminasi logam berat timbal tidak terdeteksi pada sampel. Sedangkan, kontaminasi logam berat kadmium dalam merek lipstik BL, NK, PS dan WD masing-masing adalah 0,2287, 0,2000, 0,1796 dan 0,1220 mg / kg. Hasil penelitian menunjukkan bahwa semua kontaminasi logam berat yang dianalisis tidak melebihi batas yang diatur oleh Badan Pengawasan Obat dan Makanan Republik Indonesia.

Kata Kunci: Spektrofotometri Serapan Atom, Kadmium, Lipstik, Timah

Received 05 February 2019| Revised 06 May 2019| Accepted 07 May 2019

*Corresponding author at: Siteba Street, Padang, Indonesia

E-mail address: ridhoasra@gmail.com 


\section{Introduction}

Cosmetic is used in contact with various parts of the human body such as epidermis, hair, nails, lips and external genital organs (external parts) or applied to the teeth or mucous membranes of the oral cavity with a view or for the purpose of cleaning, perfuming, protection, changing their outlook, converting body odors and keeping the surfaces in good condition[1]. Cosmetics are mixtures of some ingredients such as surfactants, oils and they need to be effective, long lasting, stable and safe to human use [2]. The various forms of cosmetic include powder, rouge (used to color the face, lighten and remove flaws to produce an impression of youth and health), lipstick and lip gloss (used to color the lips), mascara (used to enhance the eye lashes), nail polish (used to color the fingernails and toenails), eye liner and eye shadow (used to color the eye lids).

Among the cosmetic products, lipsticks have the higher risk of direct oral ingestion, aggravating the negative effects of their ingredients. Therefore, people's concern about cosmetics toxicity has become an important issue. The early lipsticks presented in the market consist of beeswax, fat and pigment as the main ingredients. The worldwide use of lipsticks has been increasing due to the willing of individual beautification [3]. Lipsticks are usually contained heavy metals such as lead and cadmium [4]. Products are presented in a wide variety of colors, produced by addition of pigments. These pigments may be mineral or organic compound and may contain heavy metals as impurities in the pigment formulation [5]. It is believed that at certain specified limits, some heavy metals could be of biological importance to human [6].

However, heavy metals such as lead and cadmium have been reported not to have any known biological importance and can be very toxic even at very low concentration [7]. Exposures to the cadmium may cause renal dysfunction and long-term exposure to cadmium can lead to obstructive of lung [6]. Cadmium is one of the heavy metals that if it is directly subjected to the human body it would decrease the blood pressure [8]. It is also connected with the diabetic[9]. Absorption of lead by the body causes inhibition of haemoglobin synthesis, kidney dysfunction, reproductive and cardiovascular systems dysfunction [6]. The toxic effects of cadmium and lead are shown via bonding to sulfydryl groups of proteins and depletion of glutathione. Lead is described as one of the most dangerous contaminants to arise in human civilization due to its distribution in environment as polluting element [10].

Therefore, it is very important to determine the concentration of these metals in lipsticks, which are used by millions of people in Padang, West Sumatera, Indonesia. The limit of heavy metals concentration which was regulated by National Agency of Drug and Food Control of the Republic of Indonesia were $20 \mathrm{mg} / \mathrm{kg}$ for lead and $5 \mathrm{mg} / \mathrm{kg}$ for cadmium. This study was to assess the public health risk from certain brands of lipsticks sold at Ramayana and Raya market in Padang. In this context, four different brands of lipsticks were selected from local markets in 
Padang, West Sumatera, Indonesia and the concentration of heavy metals such as cadmium and lead were analyzed using Atomic Absorption Spectrometry.

\section{Material and Method}

\subsection{Samples and sample collection}

Four samples of different brands of lipsticks were collected from retail shops in Ramayana and Raya Markets in Padang, West Sumatera. The samples were of different qualities and popular brands with different price ranges. The lipstick samples were assigned to codes BL, NK, PS and WD.

\subsection{Reagents and chemicals}

The following acids of the highest purity for heavy metal analysis were produced by Merck Company: $\mathrm{Pb}$ (NO3)2, Cd (NO3)2, HNO3 $65 \%$, HClO4 $60 \%$, and H2O2 $30 \%$. Working standard solutions were freshly prepared by stepwise dilution of the stock solution with distilled water. These stock solutions were serially diluted to give concentrations as below:

Cadmium: A calibration curve with different cadmium concentrations $(0.1 ; 0.2 ; 0.3 ; 0.4 ; 0.5$ $\mathrm{mg} / \mathrm{L}$ ) was prepared.

Lead: A calibration curve with different lead concentrations $(0.2 ; 0.4 ; 0.6 ; 0.8 ; 1.0 \mathrm{mg} / \mathrm{L})$ was prepared

The concentration of metal ions (lead and cadmium) was determined by atomic absorption spectrophotometry using a Varian AA 240 Atomic Absorption Spectrophotometer. Absorbance was measured with AAS at $217.0 \mathrm{~nm}$ for lead and $228.8 \mathrm{~nm}$ for cadmium. The datas were used to obtain calibration curves.

\subsection{Sample digestion and chemical analysis}

Lipsticks are in the semi solid form, so pretreatment of samples was required before analysis. For this purpose, $2.0 \mathrm{~g}$ of lipstick samples were exactly weighted with electrical analytical balance and put into Kjeldahl Flasks $50 \mathrm{~mL}$. Lipstick samples were digested by using wet digestion method by repeatedly addition of $10.0 \mathrm{ml}$ of $3: 1 \mathrm{HNO} 3 / \mathrm{HClO} 4$ at interval of 3 minutes for 5 times using the same ratio at atmospheric pressure under open system on hot plate at $100{ }^{\circ} \mathrm{C}$ and $6 \mathrm{~mL}$ of $\mathrm{H} 2 \mathrm{O} 230 \%$ was added, then heated until the white fumes started evolving, which showed the completion of digestion process. The solutions were allowed to cool, filtered by whatman no. 42 into a calibrated flask $(25 \mathrm{ml})$, and were diluted up to the mark. The sample solutions were analyzed for $\mathrm{Cd}$ at $228.8 \mathrm{~nm}$ and $\mathrm{Pb}$ at $217.0 \mathrm{~nm}$ using a Varian $\mathrm{AA}$ 240 Atomic Absorption Spectrophotometer. 


\section{Results and Discussion}

The types of lipsticks used for this study were shown in Table 1.

Table 1. Brands of lipstick used for study

\begin{tabular}{lll}
\hline Brand Names & Colours & Form \\
\hline BL & Maroone & Stick \\
NK & Maroone & Stick \\
PS & Maroone & Stick \\
WD & Maroone & Stick \\
\hline
\end{tabular}

From this study, the linear regressions of stock solutions $(\mathrm{Cd}$ and $\mathrm{Pb})$ were obtained, which were showed in Figure 1. and 2.

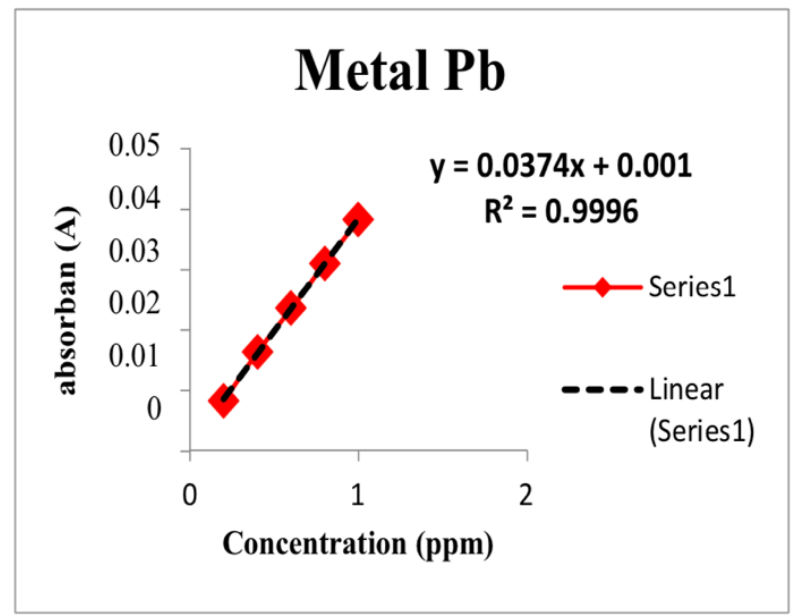

Figure 1. Calibration curve of $\mathrm{Pb}$

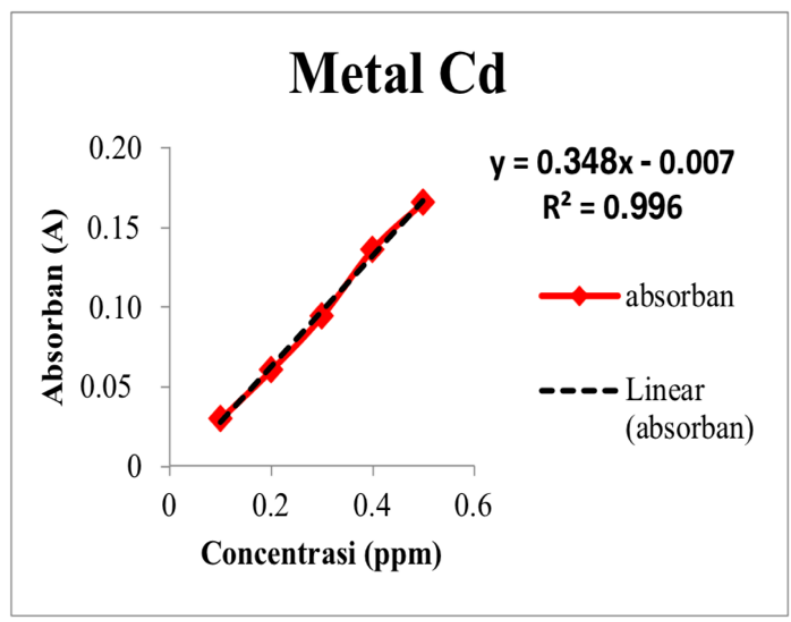

Figure 2. Calibration curve of $\mathrm{Cd}$

From Calibration curves SD, LOD and LOQ were calculated that shown in table 2.

Table 2. Standard Deviation, Limit of Detection and Limit of Quantification

\begin{tabular}{llll}
\hline Metals & SD & LOD & LOQ \\
\hline $\mathrm{Cd}$ & 0.00356 & $0.0306 \mathrm{mg} / \mathrm{Kg}$ & $0,1022 \mathrm{mg} / \mathrm{kg}$ \\
$\mathrm{Pb}$ & 0.000576 & $0.0462 \mathrm{mg} / \mathrm{Kg}$ & $0.1542 \mathrm{mg} / \mathrm{kg}$ \\
\hline
\end{tabular}

Table 3. The contents of cadmium and lead in lipstick samples

\begin{tabular}{ccccccccc}
\hline $\begin{array}{c}\text { Brand } \\
\text { Names }\end{array}$ & Repetition & $\begin{array}{c}\text { Absorpti } \\
\text { on }\end{array}$ & $\begin{array}{c}\text { Cd } \\
\text { Concent } \\
\text { ration }\end{array}$ & $\begin{array}{c}\text { Average } \\
\text { Cd } \\
\text { concentr } \\
\text { ation }\end{array}$ & $\begin{array}{c}\text { Brand } \\
\text { Names }\end{array}$ & Repetition & $\begin{array}{c}\text { Absorbtion } \\
\text { Concentrat } \\
\text { ion }\end{array}$ & $\begin{array}{c}\text { Average } \\
\text { Pb } \\
\text { concentrati } \\
\text { on }\end{array}$ \\
\hline
\end{tabular}




\begin{tabular}{|c|c|c|c|c|c|c|c|c|c|}
\hline & & & (mg/Kg) & $(\mathrm{mg} / \mathrm{Kg})$ & & & & (mg/Kg) & (mg/Kg) \\
\hline & 1 & -0.0013 & 0.22250 & & & 1 & -0.0006 & - & - \\
\hline \multirow[t]{3}{*}{$\mathrm{BL}$} & 2 & -0.0010 & 0.23375 & 0.229 & $\mathrm{BL}$ & 2 & -0.0005 & - & \\
\hline & 3 & -0.0011 & 0.23000 & & & 3 & 0.0000 & - & \\
\hline & 1 & -0.0021 & 0.19375 & & & 1 & -0.0002 & - & - \\
\hline \multirow[t]{3}{*}{ NK } & 2 & -0.0017 & 0.20875 & 0.200 & NK & 2 & -0.0001 & - & \\
\hline & 3 & -0.0020 & 0.19750 & & & 3 & 0.0004 & - & \\
\hline & 1 & -0.0019 & 0.20125 & & & 1 & -0.0730 & - & - \\
\hline \multirow[t]{3}{*}{ PS } & 2 & -0.0028 & 0.16875 & 0.179 & PS & 2 & -0.0700 & - & \\
\hline & 3 & -0.0028 & 0.16875 & & & 3 & -0.0460 & - & \\
\hline & 1 & -0.0041 & 0.12250 & & & 1 & -0.0780 & - & - \\
\hline \multirow[t]{2}{*}{ WD } & 2 & -0.0039 & 0.12875 & 0.122 & WD & 2 & -0.0890 & - & \\
\hline & 3 & -0.0043 & 0.11500 & & & 3 & -0.0830 & - & \\
\hline
\end{tabular}

The contents of cadmium and lead in lipstick samples are presented in Table 3. From Table 3, that can be seen that all the samples are negative from $\mathrm{Pb}$ ion. Concentrations of $\mathrm{Pb}$ in samples were not detected, may be caused all the samples were not containing $\mathrm{Pb}$ ion or very low concentration of ion $\mathrm{Pb}$ in samples. Then, all the samples contain various concentration $\mathrm{Cd}$ ion, some within the acceptable limits and some out of the safe range. The limited value for cadmium reported in the Literature (regulated by National Agency of Drug and Food Control of the Republic of Indonesia) is about $5 \mathrm{mg} / \mathrm{kg}$. All the samples showed cadmium in their formulation in the range of $0.1220-0.22885 \mathrm{mg} / \mathrm{Kg}$ (table 2). So, trace amount of cadmium in all tested lipsticks is safe. Although content of heavy metals in the tested lipsticks was reasonable, but the continuous use of lipsticks can increase the absorption of heavy metals into the body by swallowing or through dermal absorption of these products. Therefore, informing the users of lipsticks specially teenagers, of the harmful consequences of lip products should be a big concern. The following actions are recommended:

a. Regular monitoring of other heavy metals and chemicals used in the manufacture of cosmetics products which may cause health risks to users should be emphasized.

b. Regulatory guidelines on heavy metals in cosmetics should be formulated and enforced by relevant authorities in the manufacture of cosmetic products in Indonesia

c. Public enlightment should be organized on the harmful effects of excessive or extensive use cosmetic products.

d. Laws should be enacted in order to limit the content of heavy metals in cosmetics and other household products and items. 


\section{Conclusion}

Four samples of lipsticks were collected from local markets in Padang, were evaluated for heavy metals $(\mathrm{Cd}$ and $\mathrm{Pb})$ levels by flame atomic absorption spectrophotometer. Cadmium concentration was lower than safe limit and the lead content of the samples was not detected.

\section{Acknowledgments}

We are grateful for the technical assistance of LLDIKTI X Padang for supporting this project.

\section{Conflict of Interest}

The authors declare that there is no conflict of interest.

\section{REFERENCES}

[1] F. O. Oyedeji, G. O. Hassan, and B. B. Adeleke, "Hydroquinone and Heavy Metals Levels in Cosmetics Marketed in Nigeria," Trends in Applied Sciences Research, vol. 6, no. 7, pp. 622-639, Jul. 2011.

[2] A. Sani, M. B. Gaya, and F. A. Abubakar, "Determination of some heavy metals in selected cosmetic products sold in kano metropolis, Nigeria," Toxicology Reports, vol. 3, pp. 866-869, 2016.

[3] A. R. Soares and C. C. Nascentes, "Development of a simple method for the determination of lead in lipstick using alkaline solubilization and graphite furnace atomic absorption spectrometry," Talanta, vol. 105, pp. 272-277, Feb. 2013.

[4] I. Al-Saleh and S. Al-Enazi, "Trace metals in lipsticks," Toxicological \& Environmental Chemistry, vol. 93, no. 6, pp. 1149-1165, Jul. 2011.

[5] B. Valet, M. Mayor, F. Fitoussi, R. Capellier, M. Dormoy, and J. Ginestar, "Colouring Agents in Cosmetic Products (Excluding Hair Dyes)," Analysis of Cosmetic Products, pp. 141-152, 2007.

[6] Duruibe, J. O., Ogwuegbu, M. O. C., \& Egwurugwu, J. N. "Heavy metal pollution and human biotoxic effects". International Journal of Physical Sciences, Vol 2, No. 5, pp. 112-118, 2007.

[7] Holum, J. R. Elements of general and biological chemistry (6th ed.). New York: John Wiley and sons, 1983.

[8] E. M. Alissa and G. A. Ferns, "Heavy Metal Poisoning and Cardiovascular Disease," Journal of Toxicology, vol. 2011, pp. 1-21, 2011.

[9] J. Godt, F. Scheidig, C. Grosse-Siestrup, V. Esche, P. Brandenburg, A. Reich, and D. A. Groneberg, Journal of Occupational Medicine and Toxicology, vol. 1, no. 1, p. 22, 2006.

[10] D. R. Smith, A. R. Flegal, "Lead in the Biosphere: Recent Trends". Ambio, Vol 24, No. 1, pp. 21-23, 1995. 